\title{
Genomic strategies to understand causes of keratoconus
}

\author{
Justyna A. Karolak ${ }^{1,2} \cdot$ Marzena Gajecka $^{1,2}$
}

Received: 16 May 2016 / Accepted: 19 December 2016 / Published online: 28 December 2016

(c) The Author(s) 2016. This article is published with open access at Springerlink.com

\begin{abstract}
Keratoconus (KTCN) is a degenerative disorder of the eye characterized by the conical shape and thinning of the cornea. The abnormal structure of KTCN-affected cornea results in loss of visual acuity. While many studies examine how environmental factors influence disease development, finding the genetic triggers has been a major emphasis of KTCN research. This paper focuses on genomic strategies that were implemented for finding candidate genes, including linkage and association studies, and presents different approaches of mutation screening. The advantages and limitations of particular tools are discussed based on literature and personal experience. Since etiology underlying KTCN is complex, numerous findings indicating heterogeneity of genetic factors involved KTCN etiology are presented.
\end{abstract}

Keywords Keratoconus $\cdot$ Complex disease $\cdot$ Highthroughput methods · Next-generation sequencing .

Candidate gene

\section{Introduction}

Keratoconus (KTCN) is a degenerating, usually bilateral disorder of the eye characterized by progressive stromal

Communicated by S. Hohmann.

Marzena Gajecka

gamar@man.poznan.pl

1 Department of Genetics and Pharmaceutical Microbiology, Poznan University of Medical Sciences, Swiecickiego 4, Poznan 60-781, Poland

2 Institute of Human Genetics, Polish Academy of Sciences, Strzeszynska 32, Poznan 60-479, Poland thinning, which results in the conical shape of the cornea. These structural changes in the corneal layers induce optical aberrations, leading to a loss of visual acuity due to distorted blurred vision, which is caused by irregular astigmatism, and high myopia (Rabinowitz 1998). Although KTCN is sometimes referred to as a corneal dystrophy, it is not included in International Classification of Corneal Dystrophies (IC3D) (Weiss et al. 2008) and should be distinguished from this group of corneal diseases. However, co-occurrence of KTCN with many types of corneal dystrophies, including Avellino and Fuchs dystrophies (Igarashi et al. 2003; Salouti et al. 2010; Wilson et al. 2014), may indicate that common molecular mechanisms in the pathogenesis of these disorders are involved.

Among the general population, the estimated frequency of KTCN is 1 in 2,000 individuals (Rabinowitz 1998), although up-to-date data are not available. The prevalence of KTCN may be different according to patient ethnic origin (Gokhale 2013). The reported prevalence of the disease may also vary depending upon the different diagnostic tests used in the particular studies. The early KTCN or forme fruste KTCN are not detectable at the slit lamp during the anterior segment examination, and in these cases, assessment of the corneal topographic pattern is required to obtain the accurate diagnosis (Saad and Gatinel 2010). The first symptoms of KTCN usually appear during the second decade or early in the third decade of life. The pathogenic features of KTCN may be observed in different layers of the cornea (Fig. 1) (Sherwin and Brookes 2004). These abnormalities include changes in morphology of epithelial cells (Sykakis et al. 2012), deposition of iron particles in the epithelial basement membrane, breaks in Bowman's layer (Rabinowitz 1998), and thinning of stroma correlating with loss of collagen lamellae, altered collagen fibril orientation, and decreased keratocytes density (Patey et al. 
Fig. 1 Schematic representation of the human eye. a Representation of healthy human eye with normal corneal thickness. b Structure of the human cornea. The cornea is a complex tissue comprised of five main layers (from the anterior to posterior margin): corneal epithelium, Bowman's membrane, stroma, Descemet's membrane, and endothelium. c Human eye with keratoconus with characteristic thinning and cone-like bulging of the cornea
A

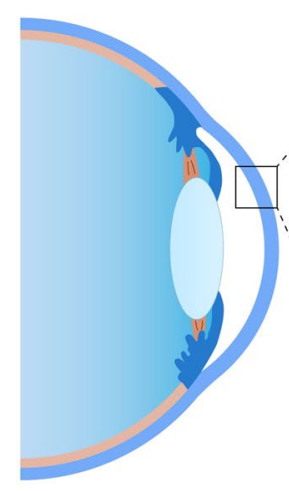

B

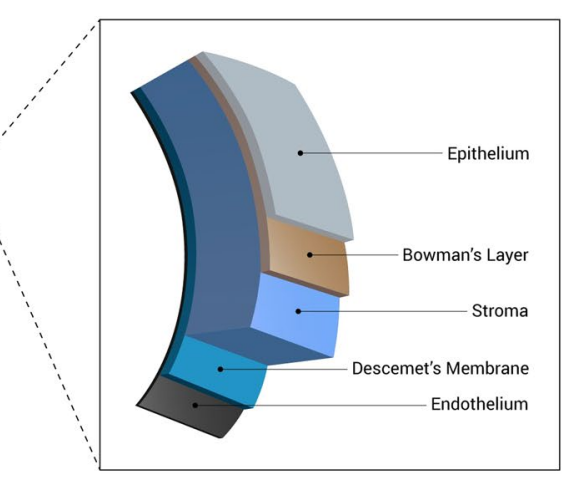

C

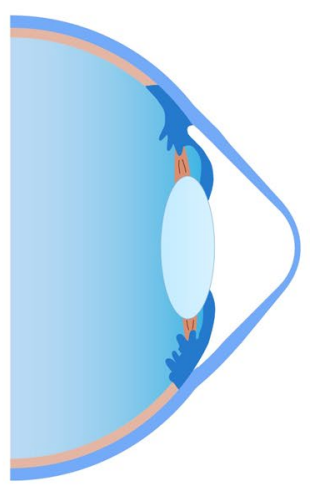

1984; Meek et al. 2005; Mathew et al. 2011). Descemet's membrane ruptures were recognized in KTCN cases with corneal hydrops (Rabinowitz 1998). The endothelium usually is not harmed in KTCN; however, sometimes, elongation and damage of endothelial cells are observed (Jeyabalan et al. 2013).

The clinical management of KTCN varies depending on the disease state and is focused on improvement of visual acuity and on the prevention of progression of the disease. Patients with the early KTCN may use spectacles or soft contact lenses. As the disease progresses, visual correction can be provided by rigid gas-permeable contact lenses, scleral lenses, or corneal collagen cross-linking. Some of the irregularities caused by mild-to-moderate KTCN may be also eliminated by insertion of intrastromal corneal ring segments. In advanced KTCN, due to progression of stromal thinning or scarring, corneal transplant surgery becomes necessary (Vazirani and Basu 2013). Corneal transplantation is required in up to $20 \%$ keratoconic eyes, thus KTCN is one of major causes for keratoplasty in developed countries (Faria-Correia et al. 2015).

Constant eye rubbing (McMonnies 2009), contact lens wear (Steahly 1978), atopy (Bawazeer et al. 2000), and UV light (Arnal et al. 2011) have been described as the major environmental and behavioral risk factors contributing to KTCN pathogenesis. Numerous genetic components, including familial inheritance (Naderan et al. 2016), a concordance between monozygotic twins in contrast to dizygotic twins (Tuft et al. 2012), and occurrence of syndromic KTCN (Elder 1994), indicate an evident genetic background of the disease. Whether KTCN is inherited according to Mendel's laws or to a non-Mendelian pattern remains unknown. Recent segregation analyses suggest that KTCN is a complex trait, likely involving multiple genes, variable penetrance, and environmental contributions (Kriszt et al. 2014).

Various tools may be adopted to understand etiology of KTCN (Fig. 2). This paper focuses on results obtained using different genetic approaches, including both simple molecular techniques and high-throughput technologies with computational and statistical methods. The advantages and limitations of particular techniques were discussed based on literature and personal experience.

\section{Linkage studies in KTCN}

Linkage studies have been performed in large KTCN families with both affected and unaffected individuals. Linkage analyses have led to the identification of 20 chromosomal regions linked to $\mathrm{KTCN}$ (Table 1). KTCN loci have been mainly determined in families of Caucasian or Hispanic origin, with further loci recognized in other ethnicities or in the populations originated from different geographical regions, including Ecuadorian, Arabic, Caribbean African, Finnish, and Northwest Tasmanian. The loci mentioned above have been identified for both isolated KTCN (e.g., $3 \mathrm{p} 14$ ) and KTCN associated with other genomic diseases, such as Leber congenital amaurosis (e.g., 17p13), which is a clinically heterogeneous group of inherited childhood retinal degenerations (Hameed et al. 2000; Brancati et al. 2004).

Among the previously reported chromosomal regions, only loci at $5 \mathrm{q}$ have been replicated (Tang et al. 2005; Li et al. 2006; Bisceglia et al. 2009; Rosenfeld et al. 2011; Bykhovskaya et al. 2016). One of them is 5q21.2 identified in Caucasians (Tang et al. 2005) and confirmed in Caucasians originated from Italy (Bykhovskaya et al. 2016). The second locus is 5q31.1-q35.3 identified in Ecuadorian KTCN family (Rosenfeld et al. 2011; Karolak et al. 2017) that overlapped 5q31 and 5q32-q33 loci, previously reported in Caucasian/Hispanic and the Southern Italian population ( $\mathrm{Li}$ et al. 2006; Bisceglia et al. 2009). The remaining KTCN susceptibility loci were representative for specific populations, small numbers of families, or most frequently, for single families only. This locus heterogeneity makes it difficult to identify genes unambiguously influencing the KTCN. 


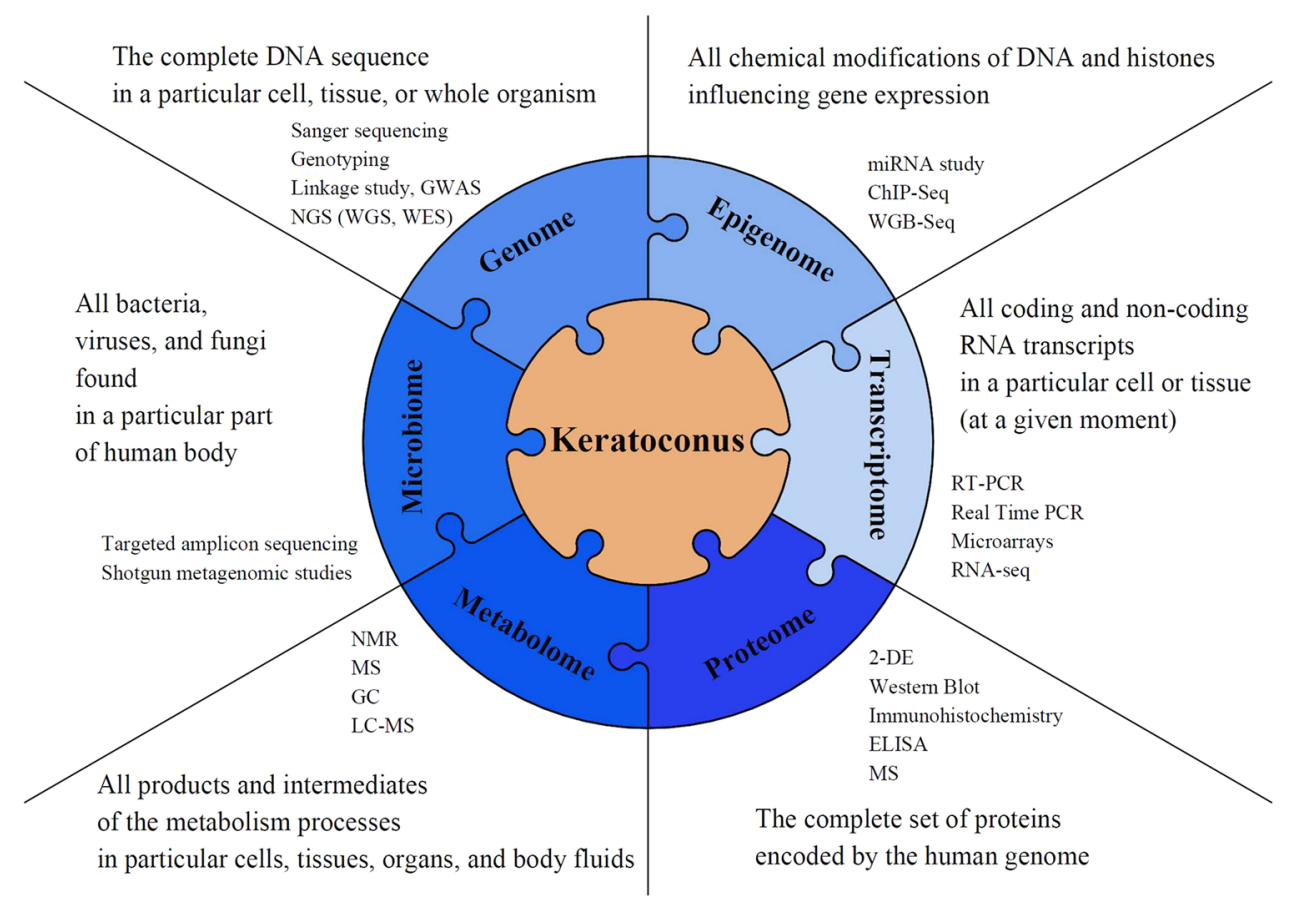

Fig. 2 Integrating biological data from multiple approaches to understand keratoconus. To understand biological processes underlying keratoconus, integrated analysis of various biological aspects may be required. The figure summarizes information on numerous areas, including DNA sequence (genome), epigenetic modifications (epigenome), RNA transcripts (transcriptome), proteins (proteome), metabolites (metabolome), and microorganisms (microbiome). Each element in the array contains examples of techniques and technologies that can be used to study particular biological aspects. List of abbre-

The finding of putative KTCN genes is additionally complicated by the fact that chromosomal intervals mapped by linkage analyses are usually large in size (up to several megabases) and contain numerous candidate genes to be further evaluated. Mutation screening of all putative genes from these regions requires substantial additional effort; thus, post-linkage analysis is often narrowed to the sequencing of a few functional genes localized in the genetic interval between markers with the maximum LOD. However, functional and positional candidate genes often do not contain variants related to the disease phenotype.

COL8A1 (collagen type VIII, alpha 1) gene, localized at 3p14-q13 KTCN is a good example for that (Brancati et al. 2004). Collagens play an important role in corneal stroma organization. Col8al and Col8a2 knock-out mice demonstrated that type VIII collagen is required for normal anterior eye development, particularly the formation of a corneal stroma (Hopfer et al. 2005). Keeping this in mind, COL8A1 gene seemed to be the best functional candidate genes at 3p14-q13 KTCN locus. Interestingly, molecular screening of coding regions of COL8Al has not revealed any potentially pathogenic variant (Brancati et al. 2004; viations: genome-wide association study (GWAS), next-generation sequencing $(N G S)$, whole-genome sequencing $(W G S)$, whole-exome sequencing (WES), reverse-transcription-PCR (RT-PCR), chromatin immunoprecipitation-sequencing (ChIP-Seq), RNA sequencing (RNA-seq), whole-genome bisulfite sequencing (WGB-seq), 2-D gel electrophoresis (2-DE), enzyme-linked immunosorbent assay (ELISA), nuclear magnetic resonance $(N M R)$, mass spectrometry $(M S)$, gas chromatography $(G C)$, liquid chromatography-mass spectrometry $(L C-M S)$

Aldave et al. 2007). Similar situation was with COLAAI and COL4A2. Since it was known that type IV collagen may be involved in KTCN (Stachs et al. 2004), these two genes localized at $13 \mathrm{q} 34$ linkage region were the first choice targets for molecular screening. Again, the analysis showed no pathogenic variants (Karolak et al. 2011).

An another issue complicating finding of putative genes in linkage regions is the fact that promising candidate genes may be localized in close proximity to the highest linkage peak and not exactly in the peak. In an Ecuadorian family, variants fully segregating with the KTCN phenotype were identified in the IPO5 (importin 5), STK24 (serine/threonine kinase 24), and DOCK9 (dedicator of cytokinesis 9) genes (Table 1). These genes are mapped in distance $(0.12$ Mbp, $0.43 \mathrm{kbp}$, and $0.34 \mathrm{Mbp}$, respectively) to FARPI (FERM, RhoGEF, and pleckstrin domain-containing protein 1), for which the maximum LOD score (4.1 in multipoint parametric linkage and 3.2 for multipoint non-parametric linkage) has been obtained. Interestingly, molecular screening of FARP1 has revealed no pathogenic variants in the affected members of the KTCN-014 family (Gajecka et al. 2009; Czugala et al. 2012). Causative genes might 


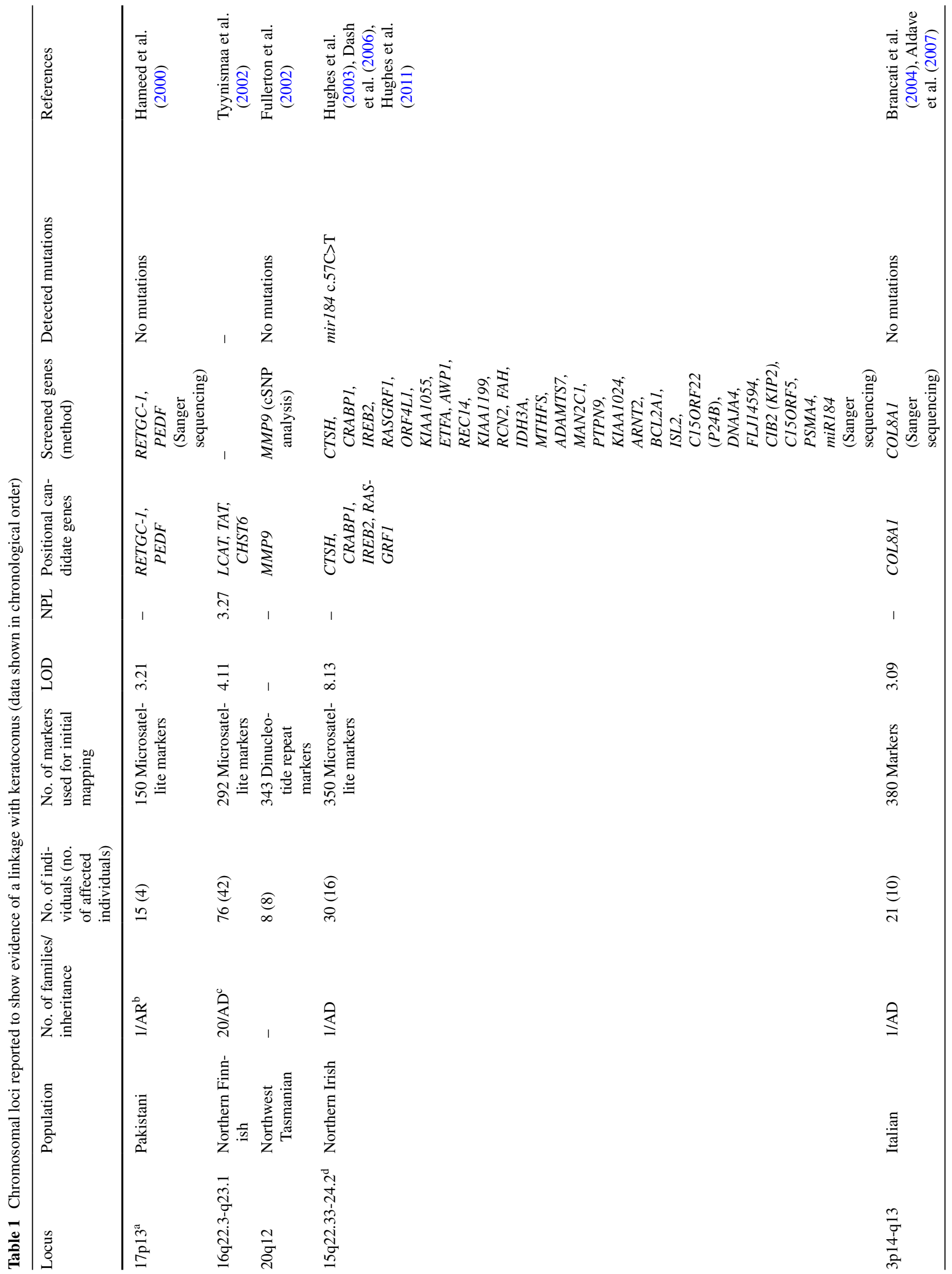




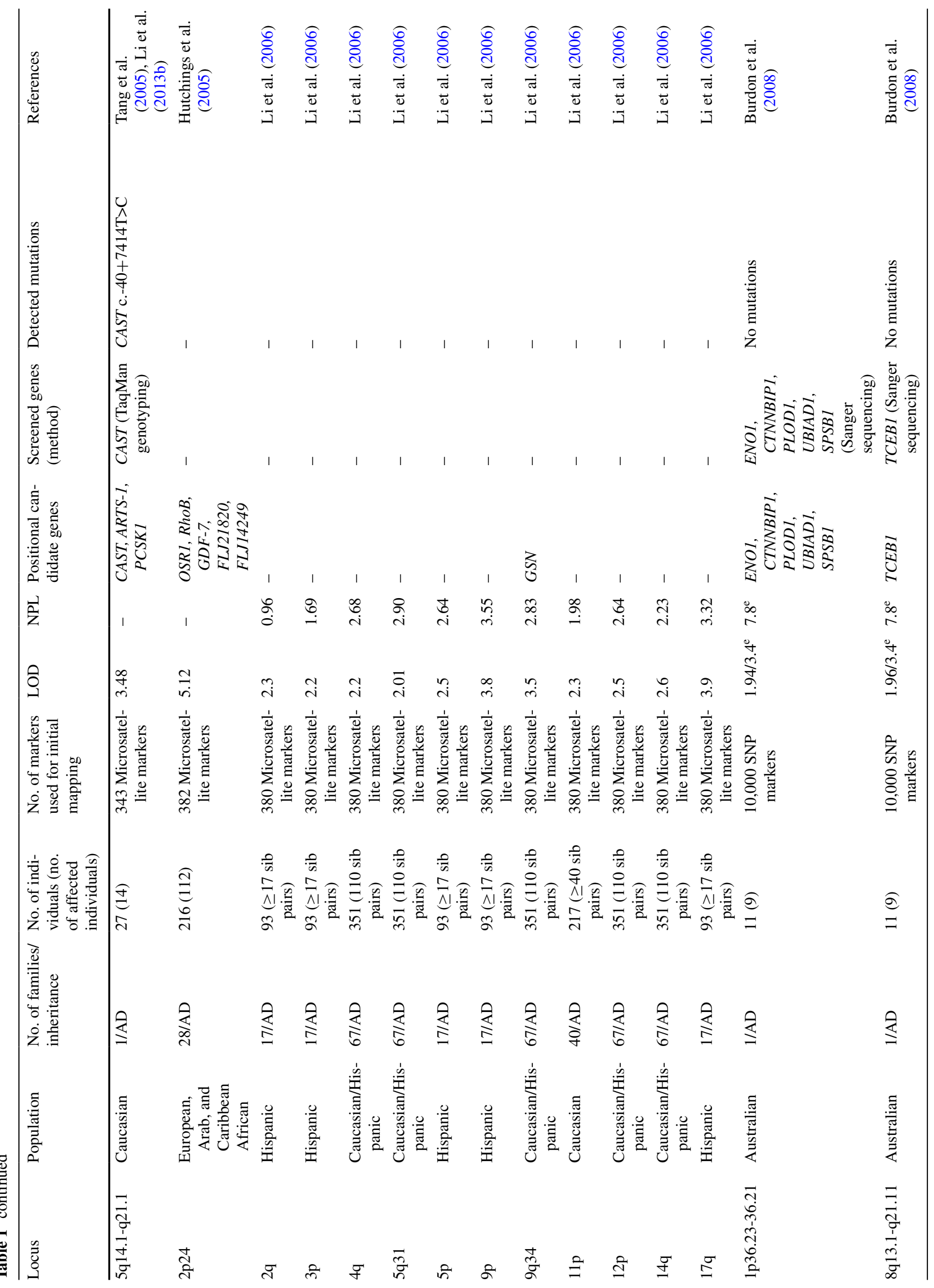




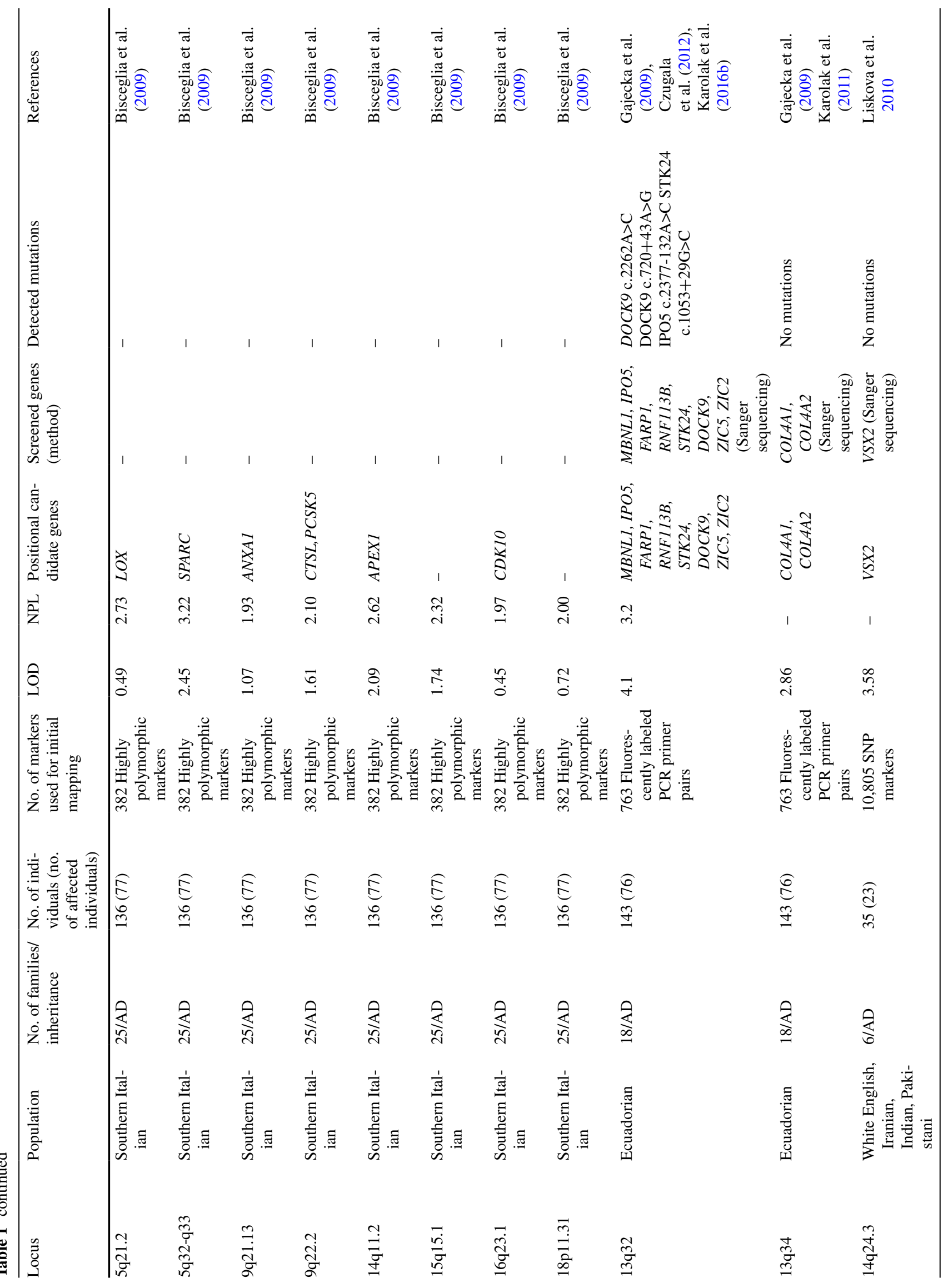




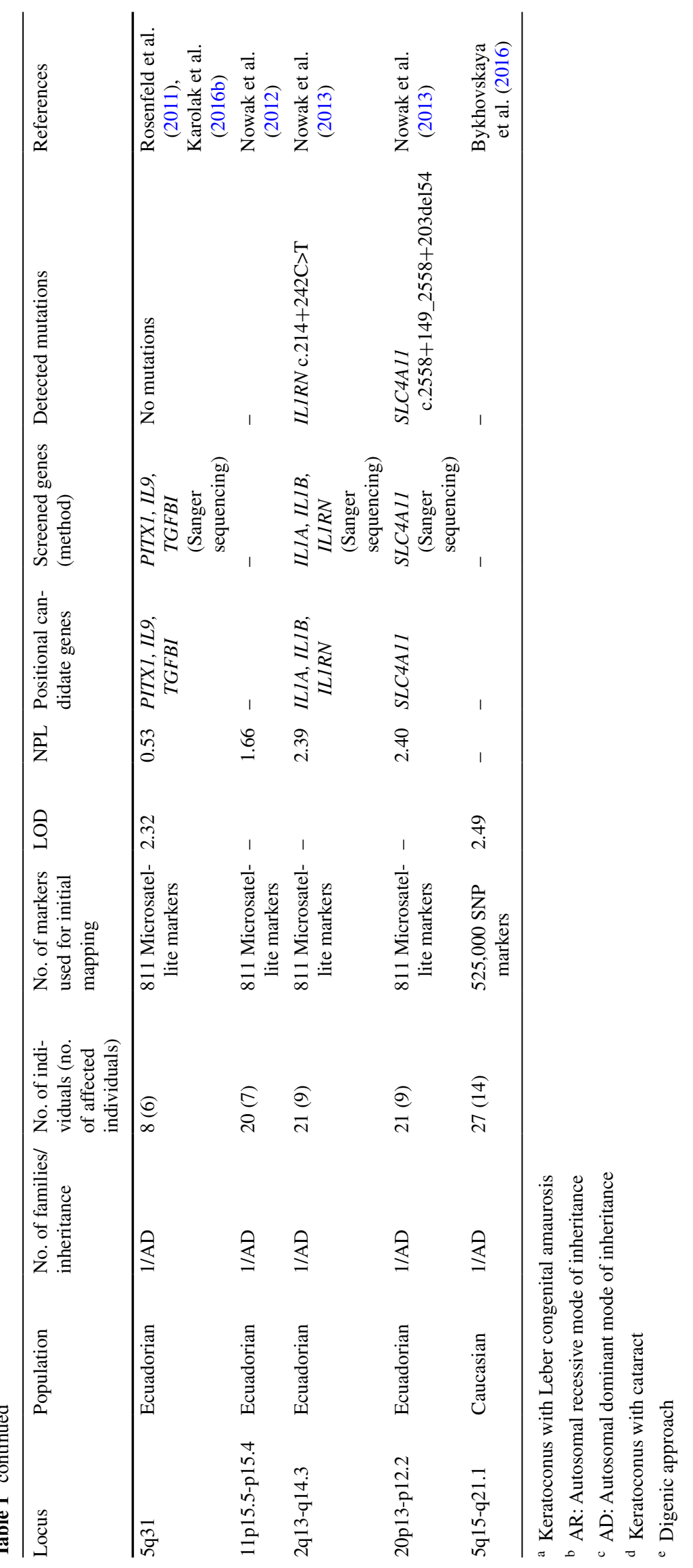


also be mapped in genomic regions with low linkage signals (Nowak et al. 2013). Screening of ILIRN (interleukin 1 receptor antagonist) and $S L C 4 A 11$ (solute carrier family 4 member 11) at 2q13-q14.3 and 20p13-p12.2 (LOD scores of 2.395 and 2.409 , respectively) has revealed variants that were observed significantly more frequently in family members with KTCN (Nowak et al. 2013).

Apart from the difficulties in selecting candidate genes for further analysis, another limitation of linkage studies is the need to ascertain a number of multigenerational families with many affected and unaffected individuals. Although some of the KTCN loci have been identified using linkage analysis of small KTCN families, no causative variants have been found in genes from those loci (Burdon and Vincent 2013). Moreover, as indicated above, some patients may have a forme fruste or early form of the disease that could not be properly recognized. Thus, some affected individuals might be classified as unaffected in the family pedigree, causing difficulties or errors in genotypephenotype correlations during linkage analyses.

\section{Relationship between sequence variation and KTCN}

An association analysis is the other approach implemented in KTCN genomic studies. One of the possible applications of this type of study is the assessment of the role of particular genetic variants in the development of KTCN. This method was used by Kim and colleagues to investigate the association between KTCN and variants in the ILIB (interleukin 1 beta) promoter gene, which may be involved in inflammatory processes in KTCN (Kim et al. 2008). The first remark about inflammatory process in KTCN eyes was reported in 1991. Fabre and co-workers showed that corneal fibroblasts presented fourfold more IL-1-binding sites than normal fibroblasts, suggesting that these corneal fibroblasts could have increased sensitivity to IL-1 compared with normal corneal fibroblasts (Fabre et al. 1991). IL-1 is critical for the inflammatory process and could participate in triggering apoptosis of the corneal cells, which might lead to the development of KTCN (Wilson et al. 1996). $\mathrm{Kim}$ and co-workers found that c.-31T $>\mathrm{C}$ and c. $-511 \mathrm{C}>\mathrm{T}$ genetic variants in the $I L I B$ were associated with a significantly increased risk of KTCN in Korean patients (Kim et al. 2008). Subsequent studies have also shown alterations in the genes involved in IL-1-dependent processes, including ILIRN gene (Nowak et al. 2013). Association of IL-1-related single-nucleotide variants (SNVs) with KTCN may suggest that some inflammatory events are responsible for KTCN (Nowak et al. 2013).

The second application of association analysis, genomewide association study (GWAS), is used to identify the common sequence variation that contributes to a disease risk. This type of study is performed in case-control cohorts with hundreds or thousands individuals and allows for genome-wide analyses due to microarray-based SNP genotyping (Manolio 2010).

The first GWAS results for KTCN were reported in 2011 by Burdon and co-workers. Analyses performed in cohorts from USA, Australia, and Northern Ireland have led to the identification of a positive association of KTCN with two SNPs, rs1014091 and rs3735520. These SNPs are localized in both the promoter and upstream region of the $H G F$ (hepatocyte growth factor) gene, which was previously reported as a high myopia gene in a Han Chinese population (Han et al. 2006; Burdon et al. 2011) (Table 2). A statistically significant association between $H G F$ and KTCN was also found in Australian patients showing that this locus might be relevant and contributed to disease susceptibility (Sahebjada et al. 2014). The HGF contains binding sites for the cytokine IL-6, which may suggest that $H G F$, like $I L I A, I L I B$, and $I L I R N$, is involved in $\mathrm{KTCN}$ through inflammatory pathways (Burdon et al. 2011).

While some sequence variants in genes involved in ILdependent processes were identified, the role of inflammatory events in KTCN remains controversial. There is no evidence of systemic inflammation, and there were no statistically significant differences in the level of inflammatory cytokines in serum between normal and KTCN individuals (Jun et al. 2011). Due to the absence of typical clinical signs of inflammation in KTCN patients, KTCN was traditionally considered as a non-inflammatory corneal disorder. However, recent proteomic studies have provided a wide spectrum of evidence of local inflammation in KTCN patients, which may support the hypothesis by McMonnies (2015) that it may be appropriate to classify KTCN as a quasi-inflammatory disease. (McMonnies 2015). Galvis and co-workers also suggested that KTCN could be, at least in part, an inflammatory condition (Galvis et al. 2015).

The other GWAS has revealed the association between rs4954218 SNP, mapped upstream of the RAB3GAPI gene (RAB3GTPase-activating protein) and $\mathrm{KTCN}$ in a Caucasian cohort from the USA ( $\mathrm{Li}$ et al. 2012). These findings were replicated in Australian Caucasian KTCN cases, providing additional evidence of significant association of rs4954218 with KTCN (Bae et al. 2013). Evidence of a genetic association was also found between KTCN and rs10519694 and rs2956540 SNPs located in the LOX (lysil oxidase) gene, encoding an enzyme responsible for collagen cross-linking in different tissues, including the cornea (Bykhovskaya et al. 2012). This association was primarily identified in two independent case-control panels and in Caucasian and Hispanic families with KTCN (Bykhovskaya et al. 2012), followed by a replication in Iranian patients (Hasanian-Langroudi et al. 2015). A most recent 
Table 2 Genome-wide significant association with keratoconus (data shown in chronological order)

\begin{tabular}{|c|c|c|c|c|c|c|c|}
\hline Gene & Population & $\begin{array}{l}\text { Discovery/replica- } \\
\text { tion cohort case/ } \\
\text { control }\end{array}$ & SNPs & $p$ value & Meta $p$ value & Genotyping methods & References \\
\hline \multicolumn{8}{|c|}{ (a) Genes identified in GWAS as associated with keratoconus } \\
\hline$H G F$ & $\begin{array}{l}\text { Australian } \\
\text { Northern Ireland }\end{array}$ & $97 / 216$ & $\begin{array}{l}\text { rs3735520 } \\
\text { rs17501108/ } \\
\text { rs1014091 }\end{array}$ & $\begin{array}{l}0.002 \\
0.0002\end{array}$ & $\begin{array}{l}9.9 \times 10^{-7} \\
9.9 \times 10^{-5}\end{array}$ & $\begin{array}{l}\text { IluminaHumanHap } \\
1 \mathrm{M}\end{array}$ & $\begin{array}{l}\text { Burdon et al. } \\
\text { (2011) }\end{array}$ \\
\hline$H G F$ & Caucasian (US) & $222 / 3324$ & $\begin{array}{l}\text { rs3735520 } \\
\text { rs17501108/ } \\
\text { rs1014091 }\end{array}$ & $\begin{array}{l}6.1 \times 10^{-7} \\
0.018\end{array}$ & $\begin{array}{l}9.9 \times 10^{-7} \\
9.9 \times 10^{-5}\end{array}$ & $\begin{array}{l}\text { Illumina } \\
\text { HumanCNV370- } \\
\text { Quad BeadChip } \\
\text { Illumina iSelect } \\
\text { Infinium }\end{array}$ & $\begin{array}{l}\text { Burdon et al. } \\
\text { (2011) }\end{array}$ \\
\hline$R A B 3 G A P 1$ & Caucasian (US) & $222 / 3324$ & rs4954218 & $2.6 \times 10^{-4}$ & $1.6 \times 10^{-7}$ & $\begin{array}{l}\text { Illumina } \\
\text { HumanCNV370- } \\
\text { Quad BeadChip } \\
\text { Illumina iSelect } \\
\text { Infinium }\end{array}$ & Li et al. (2012) \\
\hline$L O X$ & Caucasian (US) & $222 / 3324$ & $\begin{array}{l}\text { rs } 10519694 \\
\text { rs } 2956540\end{array}$ & $\begin{array}{l}2.3 \times 10^{-3} \\
7 \times 10^{-3}\end{array}$ & $\begin{array}{l}4.0 \times 10^{-5} \\
7.7 \times 10^{-4}\end{array}$ & $\begin{array}{l}\text { Illumina } \\
\text { HumanCNV370- } \\
\text { Quad BeadChip } \\
\text { Illumina iSelect } \\
\text { Infinium }\end{array}$ & $\begin{array}{l}\text { Bykhovskaya } \\
\text { et al. (2012) }\end{array}$ \\
\hline FOXO1 & $\begin{array}{l}\text { Australian/Cauca- } \\
\text { sian (US) }\end{array}$ & $874 / 6085$ & rs2721051 & $2.7 \times 10^{-10}$ & - & $\begin{array}{l}\text { Sequenom Autoflex } \\
\text { MassArray } \\
\text { Illumina Human- } \\
\text { Hap610-Quad } \\
\text { BeadChip } \\
\text { Illumina } \\
\text { HumanCNV370- } \\
\text { Quad BeadChip }\end{array}$ & Lu et al. (2013) \\
\hline$F N D C 3 B$ & $\begin{array}{l}\text { Australian/Cauca- } \\
\text { sian (US) }\end{array}$ & $874 / 6085$ & rs4894535 & $4.9 \times 10^{-9}$ & - & $\begin{array}{l}\text { Sequenom Autoflex } \\
\text { MassArray } \\
\text { Illumina Human- } \\
\text { Hap610-Quad } \\
\text { BeadChip } \\
\text { Illumina } \\
\text { HumanCNV370- } \\
\text { Quad BeadChip }\end{array}$ & Lu et al. (2013) \\
\hline$R X R A-C O L 5 A 1$ & $\begin{array}{l}\text { Australian/Cauca- } \\
\text { sian (US) }\end{array}$ & $874 / 6085$ & rs1536482 & $2.6 \times 10^{-7}$ & - & $\begin{array}{l}\text { Sequenom Autoflex } \\
\text { MassArray } \\
\text { Illumina Human- } \\
\text { Hap610-Quad } \\
\text { BeadChip } \\
\text { Illumina } \\
\text { HumanCNV370- } \\
\text { Quad BeadChip }\end{array}$ & Lu et al. (2013) \\
\hline$M P D Z-N F 1 B$ & $\begin{array}{l}\text { Australian/Cauca- } \\
\text { sian (US) }\end{array}$ & $874 / 6085$ & rs1324183 & $5.2 \times 10^{-6}$ & - & $\begin{array}{l}\text { Sequenom Autoflex } \\
\text { MassArray } \\
\text { Illumina Human- } \\
\text { Hap610-Quad } \\
\text { BeadChip } \\
\text { Illumina } \\
\text { HumanCNV370- } \\
\text { Quad BeadChip }\end{array}$ & Lu et al. (2013) \\
\hline COL5A1 & $\begin{array}{l}\text { Australian/Cauca- } \\
\text { sian (US) }\end{array}$ & $874 / 6085$ & rs7044529 & $8 \times 10^{-6}$ & - & $\begin{array}{l}\text { Sequenom Autoflex } \\
\text { MassArray } \\
\text { Illumina Human- } \\
\text { Hap610-Quad } \\
\text { BeadChip } \\
\text { Illumina } \\
\text { HumanCNV370- } \\
\text { Quad BeadChip }\end{array}$ & Lu et al. (2013) \\
\hline
\end{tabular}


Table 2 continued

\begin{tabular}{|c|c|c|c|c|c|c|c|}
\hline Gene & Population & $\begin{array}{l}\text { Discovery/replica- } \\
\text { tion cohort case/ } \\
\text { control }\end{array}$ & SNPs & $p$ value & Meta $p$ value & Genotyping methods & References \\
\hline BANP-ZNF469 & $\begin{array}{l}\text { Australian/Cauca- } \\
\quad \text { sian (US) }\end{array}$ & $874 / 6085$ & rs9938149 & $1.9 \times 10^{-4}$ & - & $\begin{array}{l}\text { Sequenom Autoflex } \\
\text { MassArray } \\
\text { Illumina Human- } \\
\text { Hap610-Quad } \\
\text { BeadChip } \\
\text { Illumina } \\
\text { HumanCNV370- } \\
\text { Quad BeadChip }\end{array}$ & Lu et al. (2013) \\
\hline COL5A1 & Caucasian (US) & $222 / 3324$ & $\begin{array}{l}\text { rs } 1536482 \\
\text { rs } 7044529\end{array}$ & $\begin{array}{l}6.5 \times 10^{-3} \\
7.4 \times 10^{-3}\end{array}$ & $\begin{array}{l}1.5 \times 10^{-4} \\
2.9 \times 10^{-3}\end{array}$ & $\begin{array}{l}\text { Illumina } \\
\text { HumanCNV370- } \\
\text { Quad BeadChip } \\
\text { Illumina iSelect } \\
\text { Infinium }\end{array}$ & Li et al. (2013a) \\
\hline \multicolumn{8}{|c|}{ (b) Genes identified in GWAS as associated with keratoconus and replicated in independent studies } \\
\hline$R A B 3 G A P 1$ & $\begin{array}{l}\text { Australian Cau- } \\
\text { casian }\end{array}$ & $524 / 2761$ & rs4954218 & $9.26 \times 10^{-9}$ & - & $\begin{array}{l}\text { Sequenom Autoflex } \\
\text { MassArray } \\
\text { Illumina Human- } \\
\text { Hap610-Quad } \\
\text { BeadChip }\end{array}$ & Bae et al. (2013) \\
\hline$M P D Z-N F 1 B$ & $\begin{array}{l}\text { Australian Cau- } \\
\text { casian }\end{array}$ & $157 / 673$ & rs 1324183 & 0.001 & - & $\begin{array}{l}\text { Sequenom Autoflex } \\
\text { MassArray }\end{array}$ & $\begin{array}{l}\text { Sahebjada et al. } \\
\text { (2013) }\end{array}$ \\
\hline$B A N P-Z N F 469$ & $\begin{array}{l}\text { Australian Cau- } \\
\text { casian }\end{array}$ & $157 / 673$ & rs9938149 & 0.010 & - & $\begin{array}{l}\text { Sequenom Autoflex } \\
\text { MassArray }\end{array}$ & $\begin{array}{l}\text { Sahebjada et al. } \\
\text { (2013) }\end{array}$ \\
\hline$H G F$ & $\begin{array}{l}\text { Australian Cau- } \\
\text { casian }\end{array}$ & $157 / 673$ & rs2286194 & $1.1 \times 10^{-3}$ & - & $\begin{array}{l}\text { Sequenom Autoflex } \\
\text { MassArray }\end{array}$ & $\begin{array}{l}\text { Sahebjada et al. } \\
\text { (2014) }\end{array}$ \\
\hline$L O X$ & Iranian & $112 / 150$ & rs 1800449 & 0.012 & - & Allele-specific PCR & $\begin{array}{l}\text { Hasanian- } \\
\text { Langroudi et al. } \\
(2015)\end{array}$ \\
\hline
\end{tabular}

GWAS has identified six loci associated with central corneal thickness and KTCN-containing polymorphisms in the FNDC3B, MPDZ-NF1B, RXRA-COL5A1, COL5A1, FOXO1, and BANP-ZNF469 genes (Lu et al. 2013). Among them, MPDZ-NF1B and BANP-ZNF469 association was confirmed by an independent study, performed in an Australian Caucasian cohort (Sahebjada et al. 2013). A detailed description of all loci reported to be associated with KTCN is presented in Table 2. The case-control association analyses between KTCN in a Saudi Arabian cohort and particular SNPs from the genomic regions of FNDC3B, MPDZNF1B, RXRA-COL5A1, FOXO1, LCN12-PTGDS, and $B A N P-Z N F 469$ did not reach the level of a statistically significant association (Abu-Amero et al. 2015a). Genotyping of the SNPs in RAB3GAP1, FNDC3B, LOX, HGF, MPDZNF1B, RXRA-COL5A1, COL5A1, FOXO1, and BANPZNF469 in the Han Chinese KTCN patients revealed that only the SNP located in MPDZ-NF1B was associated with an increased risk of KTCN in this population. No significant difference was observed between KTCN and controls in other SNPs including rs9938149 from BANP-ZNF469 genomic region (Hao et al. 2015).

Despite computational and experimental developments, the interpretation of GWAS data is still a great challenge.
Discovery of a causative variant is difficult especially if the associated sequence variant is located in a non-coding region or in a distance from known genes. These inter- and intra-genic regions of human genomes may contain regulatory elements, but a little is known regarding how particular variants affect their functions and how this influences the phenotype. Therefore, the statistically significant association of a particular SNP with a disease does not prove that this variant is actually causative for the disorder and further studies are required to assess its role in disease development.

Another limitation of GWAS analyses is the size of the study group. For complex traits, such as KTCN, meaningful results can be obtained with several hundreds or thousands of individuals with a disease phenotype. In addition, poor phenotypic classification or inconsistent phenotype exams (using different inclusion criteria in various ascertainment places) in patients may lead to false positive associations. Moreover, significant loci often explain only a small proportion of the phenotypic variation, suggesting that rare variants may underlie the genetic causes of the disease. As GWAS recognizes only common risk alleles, the locus associated with GWAS signals may be far larger than assumed. Thus, a good solution for revealing rare 
variants would be to extend the sequencing region to at least a few additional megabases around the GWAS signal (Dickson et al. 2010). Rare alleles may also be discovered through whole-exome sequencing (WES) or whole-genome sequencing (WGS) analyses, which will be discussed below.

\section{Sanger sequencing mutational screening}

For the last few decades, automated Sanger sequencing was the gold standard for human genome research. To date, numerous promising genes implicated in KTCN etiology have been analyzed using this tool (Table 3). Among them were VSX1 (visual system homeobox 1) and SOD1 (superoxide dismutase isoenzyme 1), the first two genes proposed as significant for KTCN development. The gene VSXI is mapped to chromosome 20p11.2 and encodes a vertebrate paired-like homeodomain transcription factor. It is expressed in vitro and in vivo in human keratocytes during their differentiation into myofibroblasts in response to wound healing (Barbaro et al. 2006). SOD1 is involved in oxidative stress-related processes, which may have a role in the etiology of KTCN (Udar et al. 2006). While the potentially disease-causing variants were initially identified in both genes (Héon et al. 2002; Udar et al. 2006), subsequent studies have not confirmed the original findings (Stabuc-Silih et al. 2010). As indicated in Table 3a, VSXI is the most evaluated gene in KTCN studies. To unambiguously determine the impact of VSXI on KTCN phenotype, the phenotype of corresponding mouse knock-out mutants is important. Although the Vsxl null mice were produced, their histological analyses did not show pathological alterations in the cornea (Chow et al. 2004). Considering the lack of KTCN in Vsxl knock-out mice and the absence of pathogenic variants in VSXI in general KTCN population, the role of VSXI in the pathogenesis of KTCN remains elusive.

Although the first two candidate genes, VSXI and SODI, were identified, many other genes have been assessed as causative for KTCN. However, Sanger sequencing of numerous genes with functional or positional relevance for KTCN, including VSX2 (visual system homeobox 2), CTSH (cathepsin H), CRABPl (cellular retinoic acid binding protein 1), and RASGRF1 (RAS protein-specific guanine nucleotide-releasing factor 1 ), has revealed no significant variants in KTCN patients (Table 3b) (Hughes et al. 2003; Liskova et al. 2010). The absence of causative KTCN variants in the coding regions of these genes indicates that rare coding variants are not involved in KTCN pathogenesis. While intronic variants and other regulatory elements were not assessed in those studies, the exact genotype-phenotype correlations still remain unclear.
Sanger sequencing has led to the identification of a possible KTCN-related variant, c. $2262 \mathrm{~A}>\mathrm{C}$ in DOCK9. DOCK9 encodes a protein that possesses guanosine triphosphate/ guanosine diphosphate exchange factor activity and specifically activates G-protein, CDC42, which is involved in intracellular signaling networks (Kwofie and Skowronski 2008). The identified c.2262A $>$ C substitution leads to the replacement of glutamine by histidine at the highly conserved \#754 position of the protein encoded by DOCK9, indicating that this gene might contribute to the KTCN phenotype in the analyzed Ecuadorian family (Czugala et al. 2012). Recently, the effect of c.2262A $>\mathrm{C}$ substitution in exon 20 of DOCK 9 was assessed in vitro. It was demonstrated that this particular variant has led to a splicing defect, resulting in the changed ratio between two DOCK9 isoforms: a wild-type transcript and a transcript without exon 20 (Karolak et al. 2015).

Interestingly, c.2262A $>\mathrm{C}$ in DOCK9 together with other sequence variants localized in intronic regions of DOCK 9 (c.720+43A $>$ G), IPO5 (c.2377-132A $>$ C), and STK24 $(\mathrm{c} .1053+29 \mathrm{G}>\mathrm{C})$ formed a disease-related haplotype that was carried by all affected individuals in the Ecuadorian KTCN family (Czugala et al. 2012). As mentioned above, the non-coding regions of genes contain many regulatory elements and intronic alterations, including single-nucleotide changes, which may trigger a deleterious effect on pre-messenger RNA splicing (Lomelin et al. 2010). Thus, it might be hypothesized that identification of additional three sequence variants in the $13 \mathrm{q} 32 \mathrm{KTCN}$ linked region could be non-accidental.

The ZNF469 (zinc finger protein 469) is another candidate gene screened in KTCN patients. The pathogenic mutations in ZNF469 were originally reported in patients with brittle cornea syndrome, a condition characterized by an extremely thin cornea that tends to rupture (Abu et al. 2008). It was also showed that variants in ZNF469 might contribute to central corneal thickness (CCT), which is abnormal in a wide variety of corneal diseases, including KTCN or corneal dystrophies (Lu et al. 2010, 2013; Vitart et al. 2010). The initial findings about an association between CCT and rs12447690 and rs9938149, mapped in the region upstream to ZNF469, were reported in patients from Australia and the United Kingdom, and then were replicated in Croatian and Scottish, Indian and Malays, Caucasians, and in Latinos ( $\mathrm{Lu}$ et al. 2010; Vitart et al. 2010; Vithana et al. 2011; Hoehn et al. 2012; Gao et al. 2013). The independent replication of GWAS results suggests the possible involvement of these common SNPs in CCT variation in the general population. As was indicated above, a recent GWAS for CCT and KTCN performed in the European and Asian populations has identified six loci that were strongly associated with a KTCN risk, including the locus upstream to ZNF469 (Lu et al. 2013). 
Table 3 Candidate genes screened in keratoconus patients that were not indicated in linkage and genome-wide association studies (data shown in chronological order)

\begin{tabular}{|c|c|c|c|}
\hline Studied population & Method & $\begin{array}{l}\text { No. of affected individuals/ } \\
\text { no. of unaffected individuals } \\
\text { (or no. of families) }\end{array}$ & References \\
\hline \multicolumn{4}{|c|}{ (a) VSX1 as the well-studied gene in keratoconus } \\
\hline Caucasian & PCR-SSCP, Sanger sequencing & $63 / 277$ & Héon et al. (2002) \\
\hline Italian & Sanger sequencing & $80 / 125$ & Bisceglia et al. (2005) \\
\hline Not described & Sanger sequencing & $100 / 0$ & Aldave et al. (2006) \\
\hline $\begin{array}{l}\text { British, Indians, Pakistani, Africans, } \\
\text { African-Caribbeans }\end{array}$ & Sanger sequencing & 85 families & Liskova et al. (2007) \\
\hline White population & $\begin{array}{l}\text { ABI allelic discrimination technology, } \\
\text { PCR-RFLP }\end{array}$ & $77 / 71$ & Tang et al. (2008) \\
\hline Ashkenazi Jewish & Sanger sequencing & 1 family & Eran et al. (2008) \\
\hline Korean & PCR-SSCP, Sanger sequencing & $249 / 208$ & Mok et al. (2008) \\
\hline Indian & Sanger sequencing & $66 / 100$ & Paliwal et al. (2009) \\
\hline Slovenian & Sanger sequencing & $113 / 100$ & Stabuc-Silih et al. (2010) \\
\hline European & Sanger sequencing & $66 / 100$ & Dash et al. (2010) \\
\hline Indian & Sanger sequencing & $50 / 50$ & Tanwar et al. (2010) \\
\hline Indian & Sanger sequencing & $2 / 4$ & Paliwal et al. (2011) \\
\hline Saudi Arabia & Sanger sequencing & $55 / 50$ & Abu-Amero et al. (2011) \\
\hline Iranian & Sanger sequencing, ARMS-PCR & $112 / 52$ & Saee-Rad et al. (2011) \\
\hline Korean & Sanger sequencing & $53 / 100$ & Jeoung et al. (2012) \\
\hline South Indian & Sanger sequencing & $170 / 108$ & Verma et al. (2013) \\
\hline Caucasian, Polynesian, Indian & Sanger sequencing & $47 / 10$ & Vincent et al. (2013) \\
\hline Iranian & PCR-SSCP, Sanger sequencing & $50 / 50$ & Dehkordi et al. (2013) \\
\hline Han Chinese & Sequenom Mass Array genotyping & $97 / 101$ & Wang et al. (2013) \\
\hline Greek & Sanger sequencing & $33 / 78$ & Moschos et al. (2015) \\
\hline Indian & Sanger sequencing & 8 families & Shetty et al. (2015) \\
\hline Polish & Sanger sequencing & $42 / 50$ & Karolak et al. (2016b) \\
\hline Studied populatior & Method & $\begin{array}{l}\text { Case/control (or no. } \\
\text { of families) }\end{array}$ & References \\
\hline
\end{tabular}

\begin{tabular}{lllll}
\hline (b) Other genes analyzed in keratoconus patients & & & \\
CAST & Multiethnic & TaqMan genotyping & $304 / 518$ & Li et al. (2013b) \\
COL4A3 & Slovenian & SSCA, Sanger sequencing & $104 / 157$ & Stabuc-Silih et al. (2009) \\
& Han Chinese & Sequenom Mass Array genotyping & $97 / 101$ & Wang et al. (2013) \\
& Greek & Sanger sequencing & $45 / 78$ & Kokolakis et al. (2014) \\
COL4A4 & Slovenian & SSCA, Sanger sequencing & $104 / 157$ & Stabuc-Silih et al. (2009) \\
& Han Chinese & Sequenom Mass Array genotyping & $97 / 101$ & Wang et al. (2013) \\
& Greek & Sanger sequencing & $45 / 78$ & Kokolakis et al. (2014) \\
& Iranian & Tetra-ARMS-PCR & $112 / 150$ & Saravani et al. (2015) \\
$F A S$ & Polish & HRM genotyping, TaqMan genotyp- & $264 / 300$ & Synowiec et al. (2014) \\
FASLG & Polish & ing & & Synowiec et al. (2014) \\
FEN1 & Polish & ing genotyping, TaqMan genotyp- & $264 / 300$ & Wojcik et al. (2014b) \\
$I L 1 A$ & Han Chinese & PCR-RFLP & & Wang et al. (2013) \\
$I L 1 B$ & Korean & Sequenom Mass Array genotyping & $97 / 101$ & Kim et al. (2008) \\
& Han Chinese & PCR-RFLP, Sanger sequencing & $100 / 100$ & Wang et al. (2013) \\
& Japanese & Sequenom Mass Array genotyping & $97 / 101$ & Mikami et al. (2013) \\
& Turkish & TaqMan genotyping & $169 / 390$ & Palamar et al. (2014) \\
& Turkish & PCR-RFLP & $121 / 121$ & Palamar et al. (2014) \\
\hline
\end{tabular}


Table 3 continued

\begin{tabular}{lllll}
\hline Gene & Studied population & Method & $\begin{array}{l}\text { Case/control (or no. } \\
\text { of families) }\end{array}$ & References \\
\hline LIG3 & Polish & genotyping & $283 / 300$ & Synowiec et al. (2015) \\
RAD51 & Polish & PCR-RFLP & $100 / 150$ & Synowiec et al. (2013) \\
SOD1 & Multiethnic & Sanger sequencing & 15 Probands/156 & Udar et al. (2006) \\
& Slovenian & Sanger sequencing & $113 / 100$ & Stabuc-Silih et al. (2010) \\
& Iranian & Sanger sequencing, ARMS-PCR & $112 / 52$ & Saee-Rad et al. (2011) \\
& Greek & Sanger sequencing & $33 / 78$ & Moschos et al. (2015) \\
& Saudi Arabia & Sanger sequencing & $55 / 100$ & Al-Muammar et al. \\
& & & & $(2015)$ \\
$T F$ & Polish & PCR-RFLP & $216 / 228$ & Wójcik et al. (2013) \\
$T G F B I$ & American & Sanger sequencing & 15 Probands & Udar et al. (2004) \\
& Chinese & Sanger sequencing & $30 / 30$ & Guan et al. (2012) \\
\hline
\end{tabular}

The molecular screening of ZNF469 gene identified a significant enrichment of potentially pathogenic heterozygous alleles in ZNF469 in $12.5 \%$ of European KTCN patients (Lechner et al. 2014) and in 23.0\% of Polynesian patients (Vincent et al. 2014). To determine whether genetic variants in ZNF469 truly contribute to the disease, the fulllength sequence of this gene was analyzed in unrelated Polish patients with isolated KTCN. Interestingly, sequencing revealed that average number of non-synonymous variants per one individual was comparable for KTCN and healthy Polish individuals and was 16.31 and 18.0, respectively (Karolak et al. 2016b). Based on the previous findings, it appears that the role of heterozygous variants in ZNF469 in KTCN patients should be further evaluated. The high prevalence of ZNF469 variants noted in KTCN individuals is typical for a common genetic variation observed in the general population. Moreover, the high phenotypic heterogeneity demonstrated by ZNF469 gene mutations may indicate that similar processes are involved in diseases characterized by corneal thinning, in general, rather than only in KTCN (Davidson et al. 2015; Karolak et al. 2016a).

\section{Mitochondrial studies}

In addition to the numerous sequencing studies focused on genomic DNA, a few studies have also been conducted on the level of mitochondrial DNA to identify further genetic aspects of KTCN. An analysis of mitochondrial complex I genes (ND1-ND6) in 20 Indian KTCN patients has revealed 84 variants, including two novel frameshift variants (Pathak et al. 2011). An investigation of full mitochondrial DNA extracted from blood samples of KTCN cases from Saudi Arabia has revealed mitochondrial DNA variants in $38.5 \%$ of KTCN patients. Among identified changes, only one non-synonymous variant $(\mathrm{m} .4218 \mathrm{~T}>\mathrm{A}$ in $N D 1)$ was heteroplasmic, whereas the remaining nine were homoplasmic (Abu-Amero et al. 2014). Homoplasmic mutations may lead to several diseases, but also heteroplasmic changes might be pathogenic, if the ratio between wildtype and altered mtDNA exceeds a given threshold value. The high level of heteroplasmy (74\%) in studies performed by Abu-Amero and colleagues suggests that the identified change in ND1 might be involved in KTCN (Abu-Amero et al. 2014). However, further studies are needed to determine the role of heteroplasmic changes in KTCN. As it is known that the traditional PCR followed by direct Sanger sequencing is insufficient to detect heteroplasmy, and it also lacks the necessary sensitivity to identify low levels of mosaicism (Jamuar et al. 2014; Gajecka 2016), techniques other than Sanger sequencing should be applied to assess heteroplasmy in KTCN.

Analysis of mitochondrial DNA gives insight into oxidative damage in KTCN. Oxidative stress is a consequence of the accumulation of reactive oxygen species (ROS) in different compartments of human body, including cornea, which cause a toxic effect on a number of cellular components, such as proteins, nucleic acids, and membrane phospholipids. ROS may be induced by UV light, and since the cornea is constantly exposed to the UV radiation, it is particularly vulnerable to the oxidative stress and damage from ROS (Buddi et al. 2002). The healthy cornea has several mechanisms involved in the minimization of ROS damaging effects, including both enzymatic activities and non-enzymatic pathways, which are altered in KTCN (Gondhowiardjo and van Haeringen 1993). It has been shown that besides the mitochondrial DNA damage, the level of antioxidants was decreased in KTCN corneas. Moreover, the level of oxidative stress markers was elevated, which suggested that mechanisms protecting against oxidative stress and cell degradation might be altered in this disease (Arnal et al. 2011; Wojcik et al. 2014a; Toprak 
et al. 2014). It is unclear whether oxidative cell degradation is a primary process in the disease development or it is a secondary effect.

\section{Next-generation sequencing as a tool for high-throughput data generation}

As mentioned above, sequencing of numerous candidate genes is time-consuming and labor intensive and thus may be not effective in a large-scale study. These limitations can be reduced using next-generation sequencing (NGS). Current NGS technologies offer different methods for template preparation, sequencing, visualizing, genome alignment, and assembly. Still, each NGS strategy allows for direct and complete DNA sequencing in a high-throughput manner, as well as the production of an enormous volume of low-cost reads per instrument run (Metzker 2010). Since 2005, NGS platforms have become widely available, giving an impressive range of applications. The general DNA sequencing platforms offer WGS and targeted resequencing (Koboldt et al. 2013).

Targeted resequencing allows for focusing on all genomic regions of interest in one experiment. One of the strategies of targeted sequencing is whole-exome sequencing (WES). WES is a promising tool that enables selective sequencing of nearly all protein-coding sequences. Unlike the gold standard-exon-by-exon analysis by conventional Sanger sequencing-WES is timeand cost-effective and more suitable for the precise determination of rare and unique coding sequence variants in an individual exome. The literature data provide many examples of the efficacy of WES in variants identification in both rare and common complex disorders, including ocular diseases. Rare coding sequence variants have been found in patients with the sporadic and the familial form of retinitis pigmentosa (Jinda et al. 2014; Villanueva et al. 2014) and retinal dystrophy (Ortube et al. 2014). WES studies have also been successful in identifying mutations in other ophthalmic diseases, including high myopia (Zhao et al. 2013), cone-rod dystrophy (Huang et al. 2013), and corneal intraepithelial dyskeratosis (Soler et al. 2013), while in the literature, there is only one report about WES in KTCN research (Karolak et al. 2017). Also, targeted resequencing of a subset of the human genome was used by Hughes and colleagues in a selective screen of all genes within the $5.5 \mathrm{Mb}$ region of chromosome $15 \mathrm{q} 22-\mathrm{q} 25$, which was previously reported as linked with KTCN in a Northern Irish family. That search resulted in the detection of c. $57 \mathrm{C}>\mathrm{T}$ variant in the seed region of the $m i R-184$ gene in a family with severe KTCN combined with the early onset anterior polar cataract (Hughes et al. 2003, 2011).
The variants in $m i R-184$ were also identified in four subsequent studies performed in two Chinese patients with isolated KTCN; in patients with a syndrome characterized by endothelial dystrophy, iris hypoplasia, congenital cataract, and stromal thinning (EDICT); in members of family with congenital cataracts and corneal abnormalities including KTCN, and in Greek sporadic KTCN patients (Iliff et al. 2012; Lechner et al. 2013; Bykhovskaya et al. 2015; Moschos et al. 2016). In contrast, latest studies performed in Iranian and Saudi Arabian KTCN patients revealed no significant $m i R$ - 184 variants, which may suggest that alterations in $m i R-184$ are a rare cause of KTCN alone (AbuAmero et al. 2015b; Farzadfard et al. 2016).

WES studies are restricted to determining the variants in protein-coding sequences, which constitute approximately only $1 \%$ of the whole human genome. Thus, many potentially important variants localized in the remaining parts of the genome would be missed. Other limitations of WES include both technical and post-sequencing issues. Some difficulties may result from insufficient sequencing coverage or inappropriate algorithms used for variant calling and annotation, especially in case of variants from multi-allelic sites. Despite the expanded databases and sophisticated workflows for data processing, both the narrowing of a large amount of initial data to a manageable number of variants and the filtering of candidate variants without a loss of possible causative ones are still challenging. While trio analysis (patient and both parents are included) in search of de novo mutations is quite simple, looking for hereditable mutations in large families with a complex disease, such as KTCN, could be problematic and requires additional Sanger-segregation analyses. Despite these limitations, WES is a promising tool to study genetic causes of many disorders. The increasing interest in new molecular techniques and easier access to the necessary equipment leads us to believe that this approach will be more frequently implemented in KTCN research in the near future.

As we indicated above, WES allows for analysis of the coding region of genes only. Since many DNA variants associated with diseases lie outside the coding regions of genomic DNA, WGS, which allows for the characterization of entire genomes of any size, has become a promising and more appropriate solution for research looking for the unidentified genetic causes of diseases. However, while the newest machines can process whole human genomes for only $\$ 1000$ each, WGS is not routinely used in research laboratories. An expanded computational infrastructure is required in processing and interpreting data sets of full genomes. Literature data showed that WGS may be successfully implemented in the identification of pathogenic DNA variants in genetically heterogeneous diseases, including autism spectrum disorder and the autosomal recessive retinitis pigmentosa (Jiang et al. 2013; Nishiguchi 
et al. 2013). Since locus and allelic heterogeneity has been observed in KTCN studies, it is reasonable to assume that WGS will be a useful method for assessing KTCN etiology.

\section{Epigenetic studies}

There are many changes in gene function, which are not elucidated by variations in the DNA sequence but may be explained by epigenetic modifications. Epigenetic mechanisms include, i.e., DNA methylation, and regulation of gene expression by small and non-coding RNAs. As epigenetic changes may be associated with the development and progression in several diseases, and then the epigenomic studies need to be added to molecular-based investigations of human disorders.

Methylation status in KTCN was studied in TIMP3 (tissue inhibitor of metalloproteinase 3) promoter. It was shown that overexpression of TIMP3 might induce apoptosis in corneal stromal cell cultures leading to KTCN (Matthews et al. 2007). Changes in DNA sequence of TIMP3 were not identified suggesting that alteration of TIMP3 expression might be due to epigenetic factors (De Bonis et al. 2011). However, methylation-specific quantitative PCR performed in three keratoconic and three healthy corneal tissues excluded promoter methylation in the TIMP3 (De Bonis et al. 2011). Large-scale epigenetic studies have never been implemented in KTCN research.

\section{Challenges and outlook}

- One of the issues limiting KTCN studies is a problem with the collection of the appropriate tissue for analyses. While blood samples are usually not difficult to collect from all studied individuals, the collection of whole corneal tissues or their fragment is limited to patients with corneal transplantation. Moreover, it is not possible to obtain the healthy cornea from living donors for comparative analyses. Therefore, the corneal tissues are often derived from non-KTCN individuals with other corneal events, who were referred for corneal transplantation.

- A good model for KTCN research could be cell lines derived from different parts of human corneas, i.e., corneal epithelial or endothelial cell lines, and corneal fibroblasts. However, the establishment and cultivation of cell lines are difficult and often fail. In addition, corneal cell lines as other cell lines derived from different cell types are not well characterized, have a limited life span, and may not reflect the properties of in vivo cells.

- There is sufficient data to suggest that KTCN has a strong genetic component. Based on genetic studies, it has become clear that KTCN etiology might involve more than one causing factor and the traditional molecular techniques may not be sufficient for identifying all elements involved in KTCN. The rapid advances of high-throughput molecular technologies have led to the development of innovative approaches allowing relationship analyses between disease phenotype and variations in the human genome. With increased using of next-generation sequencing technologies, it may be possible to identify genetic variants underlying the KTCN etiology.

Acknowledgements National Science Centre in Poland, Doctoral Scholarship Etiuda 1, 2013/08/T/NZ5/00754 (J.A.K.); Polish Ministry of Science and Higher Education, Grant NN 402591740 (J.A.K.); National Science Centre in Poland, Grant Sonata Bis 1, 2012/05/E/ NZ5/02127 (M.G); National Science Centre in Poland, Grant Harmonia, 2013/10/M/NZ2/00283 (M.G.); J.A.K. declares that she is a scholarship holder within the project "Scholarship support for Ph.D. students specializing in majors strategic for Wielkopolska's development", Sub-measure 8.2.2 Human Capital Operational Programme, co-financed by the European Union under the European Social Fund.

\section{Compliance with ethical standards}

Conflict of interest Justyna A. Karolak and Marzena Gajecka declare that they have no conflict of interest.

Ethical approval This article does not contain any studies with human participants or animals performed by the authors.

Open Access This article is distributed under the terms of the Creative Commons Attribution 4.0 International License (http://creativecommons.org/licenses/by/4.0/), which permits unrestricted use, distribution, and reproduction in any medium, provided you give appropriate credit to the original author(s) and the source, provide a link to the Creative Commons license, and indicate if changes were made.

\section{References}

Abu A, Frydman M, Marek D et al (2008) Deleterious mutations in the Zinc-Finger 469 gene cause brittle cornea syndrome. Am J Hum Genet 82:1217-1222. doi:10.1016/j.ajhg.2008.04.001

Abu-Amero KK, Kalantan H, Al-Muammar AM (2011) Analysis of the VSX1 gene in keratoconus patients from Saudi Arabia. Mol Vis 17:667-672

Abu-Amero KK, Azad TA, Kalantan H et al (2014) Mitochondrial sequence changes in keratoconus patients. Invest Ophthalmol Vis Sci 55:1706-1710. doi:10.1167/iovs.14-13938

Abu-Amero KK, Helwa I, Al-Muammar A et al (2015a) Case-control association between CCT-associated variants and keratoconus in a Saudi Arabian population. J Negat Results Biomed 14:10. doi:10.1186/s12952-015-0029-5

Abu-Amero KK, Helwa I, Al-Muammar A et al (2015b) Screening of the seed region of MIR184 in keratoconus patients from Saudi Arabia. BioMed Res Int 2015:604508. doi: $10.1155 / 2015 / 604508$

Aldave AJ, Yellore VS, Salem AK et al (2006) No VSX1 gene mutations associated with keratoconus. Invest Ophthalmol Vis Sci 47:2820-2822. doi:10.1167/iovs.05-1530 
Aldave AJ, Bourla N, Yellore VS et al (2007) Keratoconus is not associated with mutations in COL8A1 and COL8A2. Cornea 26:963-965. doi:10.1097/ICO.0b013e31811dfaf7

Al-Muammar AM, Kalantan H, Azad TA et al (2015) Analysis of the SOD1 gene in keratoconus patients from Saudi Arabia. Ophthalmic Genet 36:373-375. doi:10.3109/13816810.2014.889173

Arnal E, Peris-Martínez C, Menezo JL et al (2011) Oxidative stress in keratoconus? Invest Ophthalmol Vis Sci 52:8592-8597. doi:10.1167/iovs.11-7732

Bae HA, Mills RAD, Lindsay RG et al (2013) Replication and meta-analysis of candidate loci identified variation at RAB3GAP1 associated with keratoconus. Invest Ophthalmol Vis Sci 54:5132-5135. doi:10.1167/iovs.13-12377

Barbaro V, Di Iorio E, Ferrari S et al (2006) Expression of VSX1 in human corneal keratocytes during differentiation into myofibroblasts in response to wound healing. Invest Ophthalmol Vis Sci 47:5243-5250. doi:10.1167/iovs.06-0185

Bawazeer AM, Hodge WG, Lorimer B (2000) Atopy and keratoconus: a multivariate analysis. Br J Ophthalmol 84:834-836

Bisceglia L, Ciaschetti M, De Bonis P et al (2005) VSX1 mutational analysis in a series of Italian patients affected by keratoconus: detection of a novel mutation. Invest Ophthalmol Vis Sci 46:3945. doi:10.1167/iovs.04-0533

Bisceglia L, De Bonis P, Pizzicoli C et al (2009) Linkage analysis in keratoconus: replication of locus $5 \mathrm{q} 21.2$ and identification of other suggestive Loci. Invest Ophthalmol Vis Sci 50:10811086. doi:10.1167/iovs.08-2382

Brancati F, Valente EM, Sarkozy A et al (2004) A locus for autosomal dominant keratoconus maps to human chromosome 3p14-q13. J Med Genet 41:188-192

Buddi R, Lin B, Atilano SR et al (2002) Evidence of oxidative stress in human corneal diseases. J Histochem Cytochem Off J Histochem Soc 50:341-351

Burdon KP, Vincent AL (2013) Insights into keratoconus from a genetic perspective. Clin Exp Optom 96:146-154. doi:10.1111/ cxo. 12024

Burdon KP, Coster DJ, Charlesworth JC et al (2008) Apparent autosomal dominant keratoconus in a large Australian pedigree accounted for by digenic inheritance of two novel loci. Hum Genet 124:379-386. doi:10.1007/s00439-008-0555-z

Burdon KP, Macgregor S, Bykhovskaya Y et al (2011) Association of polymorphisms in the hepatocyte growth factor gene promoter with keratoconus. Invest Ophthalmol Vis Sci 52:8514-8519. doi:10.1167/iovs.11-8261

Bykhovskaya Y, Li X, Epifantseva I et al (2012) Variation in the lysyl oxidase (LOX) gene is associated with keratoconus in familybased and case-control studies. Invest Ophthalmol Vis Sci 53:4152-4157. doi:10.1167/iovs.11-9268

Bykhovskaya Y, Caiado Canedo AL, Wright KW, Rabinowitz YS (2015) C.57 C > T mutation in MIR 184 is responsible for congenital cataracts and corneal abnormalities in a five-generation family from Galicia, Spain. Ophthalmic Genet 36:244-247. doi: 10.3109/13816810.2013.848908

Bykhovskaya Y, Li X, Taylor KD et al (2016) Linkage analysis of high-density SNPs confirms keratoconus locus at 5q chromosomal region. Ophthalmic Genet 37:109-110. doi:10.3109/138 16810.2014.889172

Chow RL, Volgyi B, Szilard RK et al (2004) Control of late offcenter cone bipolar cell differentiation and visual signaling by the homeobox gene Vsx1. Proc Natl Acad Sci USA 101:17541759. doi:10.1073/pnas.0306520101

Czugala M, Karolak JA, Nowak DM et al (2012) Novel mutation and three other sequence variants segregating with phenotype at keratoconus 13q32 susceptibility locus. Eur J Hum Genet EJHG 20:389-397. doi:10.1038/ejhg.2011.203
Dash DP, Silvestri G, Hughes AE (2006) Fine mapping of the keratoconus with cataract locus on chromosome $15 \mathrm{q}$ and candidate gene analysis. Mol Vis 12:499-505

Dash DP, George S, O'Prey D et al (2010) Mutational screening of VSX1 in keratoconus patients from the European population. Eye Lond Engl 24:1085-1092. doi:10.1038/eye.2009.217

Davidson AE, Borasio E, Liskova P et al (2015) Brittle cornea syndrome ZNF469 mutation carrier phenotype and segregation analysis of rare ZNF469 variants in familial keratoconus. Invest Ophthalmol Vis Sci 56:578-586. doi:10.1167/iovs.14-15792

De Bonis P, Laborante A, Pizzicoli C et al (2011) Mutational screening of VSX1, SPARC, SOD1, LOX, and TIMP3 in keratoconus. Mol Vis 17:2482-2494

Dehkordi FA, Rashki A, Bagheri N et al (2013) Study of VSX1 mutations in patients with keratoconus in southwest Iran using PCR-single-strand conformation polymorphism/heteroduplex analysis and sequencing method. Acta Cytol 57:646-651. doi:10.1159/000353297

Dickson SP, Wang K, Krantz I et al (2010) Rare variants create synthetic genome-wide associations. PLoS Biol 8:e1000294. doi:10.1371/journal.pbio.1000294

Elder MJ (1994) Leber congenital amaurosis and its association with keratoconus and keratoglobus. J Pediatr Ophthalmol Strabismus 31:38-40

Eran P, Almogit A, David Z et al (2008) The D144E substitution in the VSX1 gene: a non-pathogenic variant or a disease causing mutation? Ophthalmic Genet 29:53-59. doi:10.1080/13816810802008242

Fabre EJ, Bureau J, Pouliquen Y, Lorans G (1991) Binding sites for human interleukin 1 alpha, gamma interferon and tumor necrosis factor on cultured fibroblasts of normal cornea and keratoconus. Curr Eye Res 10:585-592

Faria-Correia F, Luz A, Ambrósio R Jr (2015) Managing corneal ectasia prior to keratoplasty. Expert Rev Ophthalmol 10:33-48. doi: 10.1586/17469899.2015.991390

Farzadfard A, Nassiri N, Moghadam TN et al (2016) Screening for MIR184 mutations in Iranian patients with keratoconus. J Ophthalmic Vis Res 11:3-7. doi:10.4103/2008-322X.180715

Fullerton J, Paprocki P, Foote S et al (2002) Identity-by-descent approach to gene localisation in eight individuals affected by keratoconus from north-west Tasmania, Australia. Hum Genet 110:462-470. doi:10.1007/s00439-002-0705-7

Gajecka M (2016) Unrevealed mosaicism in the next-generation sequencing era. Mol Genet Genomics MGG 291:513-530. doi:10.1007/s00438-015-1130-7

Gajecka M, Radhakrishna U, Winters D et al (2009) Localization of a gene for keratoconus to a 5.6-Mb interval on $13 \mathrm{q} 32$. Invest Ophthalmol Vis Sci 50:1531-1539. doi:10.1167/iovs.08-2173

Galvis V, Sherwin T, Tello A et al (2015) Keratoconus: an inflammatory disorder? Eye Lond Engl 29:843-859. doi:10.1038/ eye. 2015.63

Gao X, Gauderman WJ, Liu Y et al (2013) A genome-wide association study of central corneal thickness in Latinos. Invest Ophthalmol Vis Sci 54:2435-2443. doi:10.1167/iovs.13-11692

Gokhale NS (2013) Epidemiology of keratoconus. Indian J Ophthalmol 61:382-383. doi:10.4103/0301-4738.116054

Gondhowiardjo TD, van Haeringen NJ (1993) Corneal aldehyde dehydrogenase, glutathione reductase, and glutathione S-transferase in pathologic corneas. Cornea 12:310-314

Guan T, Liu C, Ma Z, Ding S (2012) The point mutation and polymorphism in keratoconus candidate gene TGFBI in Chinese population. Gene 503:137-139. doi:10.1016/j.gene.2012.04.061

Hameed A, Khaliq S, Ismail M et al (2000) A novel locus for Leber congenital amaurosis (LCA4) with anterior keratoconus mapping to chromosome 17p13. Invest Ophthalmol Vis Sci 41:629-633 
Han W, Yap MKH, Wang J, Yip SP (2006) Family-based association analysis of hepatocyte growth factor (HGF) gene polymorphisms in high myopia. Invest Ophthalmol Vis Sci 47:22912299. doi:10.1167/iovs.05-1344

Hao X-D, Chen P, Chen Z-L et al (2015) Evaluating the Association between Keratoconus and Reported Genetic Loci in a Han Chinese Population. Ophthalmic Genet 36:132-136. doi:10.3109/1 3816810.2015 .1005317

Hasanian-Langroudi F, Saravani R, Validad M-H et al (2015) Association of lysyl oxidase (LOX) polymorphisms with the risk of keratoconus in an Iranian population. Ophthalmic Genet 36:309-314. doi:10.3109/13816810.2014.881507

Héon E, Greenberg A, Kopp KK et al (2002) VSX1: a gene for posterior polymorphous dystrophy and keratoconus. Hum Mol Genet 11:1029-1036

Hoehn R, Zeller T, Verhoeven VJM et al (2012) Population-based meta-analysis in Caucasians confirms association with COL5A1 and ZNF469 but not COL8A2 with central corneal thickness. Hum Genet 131:1783-1793. doi:10.1007/s00439-012-1201-3

Hopfer U, Fukai N, Hopfer H et al (2005) Targeted disruption of Col8a1 and Col8a2 genes in mice leads to anterior segment abnormalities in the eye. FASEB J Off Publ Fed Am Soc Exp Biol 19:1232-1244. doi:10.1096/fj.04-3019com

Huang L, Zhang Q, Li S et al (2013) Exome sequencing of 47 Chinese families with cone-rod dystrophy: mutations in 25 known causative genes. PLoS One 8:e65546. doi:10.1371/journal. pone. 0065546

Hughes AE, Dash DP, Jackson AJ et al (2003) Familial keratoconus with cataract: linkage to the long arm of chromosome 15 and exclusion of candidate genes. Invest Ophthalmol Vis Sci 44:5063-5066

Hughes AE, Bradley DT, Campbell M et al (2011) Mutation altering the miR-184 seed region causes familial keratoconus with cataract. Am J Hum Genet 89:628-633. doi:10.1016/j. ajhg.2011.09.014

Hutchings H, Ginisty H, Le Gallo $M$ et al (2005) Identification of a new locus for isolated familial keratoconus at 2 p24. J Med Genet 42:88-94. doi:10.1136/jmg.2004.022103

Igarashi S, Makita Y, Hikichi T et al (2003) Association of keratoconus and avellino corneal dystrophy. $\mathrm{Br} \mathrm{J}$ Ophthalmol $87: 367-368$

Iliff BW, Riazuddin SA, Gottsch JD (2012) A single-base substitution in the seed region of miR-184 causes EDICT syndrome. Invest Ophthalmol Vis Sci 53:348-353. doi:10.1167/iovs.11-8783

Jamuar SS, Lam A-TN, Kircher M et al (2014) Somatic mutations in cerebral cortical malformations. N Engl J Med 371:733-743. doi:10.1056/NEJMoa1314432

Jeoung JW, Kim MK, Park SS et al (2012) VSX1 gene and keratoconus: genetic analysis in Korean patients. Cornea 31:746-750. doi:10.1097/ICO.0b013e3181e16dd0

Jeyabalan N, Shetty R, Ghosh A et al (2013) Genetic and genomic perspective to understand the molecular pathogenesis of keratoconus. Indian J Ophthalmol 61:384-388. doi:10.4103/0301-4738.116055

Jiang Y, Yuen RKC, Jin X et al (2013) Detection of clinically relevant genetic variants in autism spectrum disorder by whole-genome sequencing. Am J Hum Genet 93:249-263. doi:10.1016/j. ajhg.2013.06.012

Jinda W, Taylor TD, Suzuki Y et al (2014) Whole exome sequencing in Thai patients with retinitis pigmentosa reveals novel mutations in six genes. Invest Ophthalmol Vis Sci 55:2259-2268. doi:10.1167/iovs.13-13567

Jun AS, Cope L, Speck C et al (2011) Subnormal cytokine profile in the tear fluid of keratoconus patients. PLoS One 6:e16437. doi:10.1371/journal.pone.0016437
Karolak JA, Kulinska K, Nowak DM et al (2011) Sequence variants in COL4A1 and COL4A2 genes in Ecuadorian families with keratoconus. Mol Vis 17:827-843

Karolak JA, Rydzanicz M, Ginter-Matuszewska B et al (2015) Variant c.2262A $>\mathrm{C}$ in DOCK9 leads to exon skipping in keratoconus family. Invest Ophthalmol Vis Sci 56:7687-7690. doi:10.1167/ iovs. $15-17538$

Karolak JA, Gambin T, Rydzanicz M et al (2016a) Evidence against ZNF469 being causative for keratoconus in Polish patients. Acta Ophthalmol (Copenh) 94:289-294. doi:10.1111/aos.12968

Karolak JA, Polakowski P, Szaflik J et al (2016b) Molecular Screening of Keratoconus Susceptibility Sequence Variants in VSX1, TGFBI, DOCK9, STK24, and IPO5 Genes in Polish Patients and Novel TGFBI Variant Identification. Ophthalmic Genet 37:37-43. doi:10.3109/13816810.2014.926375

Karolak JA, Gambin T, Pitarque JA et al (2017) Variants in SKP1, PROB1, and IL17B genes at keratoconus 5q31.1-q35.3 susceptibility locus identified by whole-exome sequencing. Eur J Hum Genet 25:73-78. doi:10.1038/ejhg.2016.130

Kim S-H, Mok J-W, Kim H-S, Joo CK (2008) Association of -31T>C and $-511 \mathrm{C}>\mathrm{T}$ polymorphisms in the interleukin 1 beta (IL1B) promoter in Korean keratoconus patients. Mol Vis 14:2109-2116

Koboldt DC, Steinberg KM, Larson DE et al (2013) The next-generation sequencing revolution and its impact on genomics. Cell 155:27-38. doi:10.1016/j.cell.2013.09.006

Kokolakis NS, Gazouli M, Chatziralli IP et al (2014) Polymorphism analysis of COL4A3 and COL4A4 genes in Greek patients with keratoconus. Ophthalmic Genet 35:226-228. doi:10.3109/13816 810.2014 .946055

Kriszt A, Losonczy G, Berta A et al (2014) Segregation analysis suggests that keratoconus is a complex non-mendelian disease. Acta Ophthalmol (Copenh) 92:e562-e568. doi:10.1111/ aos. 12389

Kwofie MA, Skowronski J (2008) Specific recognition of Rac2 and Cdc42 by DOCK2 and DOCK9 guanine nucleotide exchange factors. J Biol Chem 283:3088-3096. doi:10.1074/jbc. M705170200

Lechner J, Bae HA, Guduric-Fuchs J et al (2013) Mutational analysis of MIR184 in sporadic keratoconus and myopia. Invest Ophthalmol Vis Sci 54:5266-5272. doi:10.1167/iovs.13-12035

Lechner J, Porter LF, Rice A et al (2014) Enrichment of pathogenic alleles in the brittle cornea gene, ZNF469, in keratoconus. Hum Mol Genet 23:5527-5535. doi:10.1093/hmg/ddu253

Li X, Rabinowitz YS, Tang YG et al (2006) Two-stage genome-wide linkage scan in keratoconus sib pair families. Invest Ophthalmol Vis Sci 47:3791-3795. doi:10.1167/iovs.06-0214

Li X, Bykhovskaya Y, Haritunians T et al (2012) A genome-wide association study identifies a potential novel gene locus for keratoconus, one of the commonest causes for corneal transplantation in developed countries. Hum Mol Genet 21:421-429. doi: $10.1093 / \mathrm{hmg} / \mathrm{ddr} 460$

Li X, Bykhovskaya Y, Canedo ALC et al (2013a) Genetic association of COL5A1 variants in keratoconus patients suggests a complex connection between corneal thinning and keratoconus. Invest Ophthalmol Vis Sci 54:2696-2704. doi:10.1167/iovs.13-11601

Li X, Bykhovskaya Y, Tang YG et al (2013b) An association between the calpastatin (CAST) gene and keratoconus. Cornea 32:696701. doi:10.1097/ICO.0b013e3182821c1c

Liskova P, Ebenezer ND, Hysi PG et al (2007) Molecular analysis of the VSX1 gene in familial keratoconus. Mol Vis 13:1887-1891

Liskova P, Hysi PG, Waseem N et al (2010) Evidence for keratoconus susceptibility locus on chromosome 14: a genome-wide linkage screen using single-nucleotide polymorphism markers. Arch Ophthalmol Chic ill 128(9):1191-1195. doi:10.1001/ archophthalmol.2010.200 
Lomelin D, Jorgenson E, Risch N (2010) Human genetic variation recognizes functional elements in noncoding sequence. Genome Res 20:311-319. doi:10.1101/gr.094151.109

Lu Y, Dimasi DP, Hysi PG et al (2010) Common genetic variants near the Brittle Cornea syndrome locus ZNF469 influence the blinding disease risk factor central corneal thickness. PLoS Genet 6:e1000947. doi:10.1371/journal.pgen.1000947

Lu Y, Vitart V, Burdon KP et al (2013) Genome-wide association analyses identify multiple loci associated with central corneal thickness and keratoconus. Nat Genet 45:155-163. doi:10.1038/ ng. 2506

Manolio TA (2010) Genomewide association studies and assessment of the risk of disease. N Engl J Med 363:166-176. doi:10.1056/ NEJMra0905980

Mathew JH, Goosey JD, Bergmanson JPG (2011) Quantified histopathology of the keratoconic cornea. Optom Vis Sci Off Publ Am Acad Optom 88:988-997. doi:10.1097/OPX.0b013e31821ffbd4

Matthews FJ, Cook SD, Majid MA et al (2007) Changes in the balance of the tissue inhibitor of matrix metalloproteinases (TIMPs)-1 and -3 may promote keratocyte apoptosis in keratoconus. Exp Eye Res 84:1125-1134. doi:10.1016/j. exer.2007.02.013

McMonnies CW (2009) Mechanisms of rubbing-related corneal trauma in keratoconus. Cornea 28:607-615. doi:10.1097/ ICO.0b013e318198384f

McMonnies CW (2015) Inflammation and keratoconus. Optom Vis Sci Off Publ Am Acad Optom 92:e35-e41. doi:10.1097/ OPX.0000000000000455

Meek KM, Tuft SJ, Huang Y et al (2005) Changes in collagen orientation and distribution in keratoconus corneas. Invest Ophthalmol Vis Sci 46:1948-1956. doi:10.1167/iovs.04-1253

Metzker ML (2010) Sequencing technologies-the next generation. Nat Rev Genet 11:31-46. doi:10.1038/nrg2626

Mikami T, Meguro A, Teshigawara T et al (2013) Interleukin 1 beta promoter polymorphism is associated with keratoconus in a Japanese population. Mol Vis 19:845-851

Mok J-W, Baek S-J, Joo C-K (2008) VSX1 gene variants are associated with keratoconus in unrelated Korean patients. J Hum Genet 53:842-849. doi:10.1007/s10038-008-0319-6

Moschos MM, Kokolakis N, Gazouli M et al (2015) Polymorphism Analysis of VSX1 and SOD1 genes in Greek patients with keratoconus. Ophthalmic Genet 36:213-217. doi:10.3109/1381681 0.2013 .843712

Moschos MM, Droutsas K, Sioziou A et al (2016) Mutational analysis of Pre-miR-184 and hsa-mir-568 in Greek patients with sporadic keratoconus. Cornea 35:631-633. doi:10.1097/ ICO.0000000000000769

Naderan M, Rajabi MT, Zarrinbakhsh P et al (2016) Association between family history and keratoconus severity. Curr Eye Res. doi:10.3109/02713683.2015.1128553

Nishiguchi KM, Tearle RG, Liu YP et al (2013) Whole genome sequencing in patients with retinitis pigmentosa reveals pathogenic DNA structural changes and NEK2 as a new disease gene. Proc Natl Acad Sci USA 110:16139-16144. doi:10.1073/ pnas. 1308243110

Nowak D, Pitarque J, Molinari A et al (2012) Linkage analysis as an approach for disease-related loci identification. Comput Methods Sci Technol 18:95-101. doi:10.12921/ cmst.2012.18.02.95-101

Nowak DM, Karolak JA, Kubiak J et al (2013) Substitution at IL1RN and deletion at SLC4A11 segregating with phenotype in familial keratoconus. Invest Ophthalmol Vis Sci 54:2207-2215. doi:10.1167/iovs.13-11592

Ortube MC, Strom SP, Nelson SF et al (2014) Whole exome sequencing detects homozygosity for ABCA4 p.Arg602Trp missense mutation in a pediatric patient with rapidly progressive retinal dystrophy. BMC Med Genet 15:11. doi:10.1186/14712350-15-11

Palamar M, Onay H, Ozdemir TR et al (2014) Relationship between IL1 $\beta-511 C>$ T and ILRN VNTR polymorphisms and keratoconus. Cornea 33:145-147. doi:10.1097/ICO.0000000000000027

Paliwal P, Singh A, Tandon R et al (2009) A novel VSX1 mutation identified in an individual with keratoconus in India. Mol Vis 15:2475-2479

Paliwal P, Tandon R, Dube D et al (2011) Familial segregation of a VSX1 mutation adds a new dimension to its role in the causation of keratoconus. Mol Vis 17:481-485

Patey A, Savoldelli M, Pouliquen Y (1984) Keratoconus and normal cornea: a comparative study of the collagenous fibers of the corneal stroma by image analysis. Cornea 3:119-124

Pathak D, Nayak B, Singh M et al (2011) Mitochondrial complex 1 gene analysis in keratoconus. Mol Vis 17:1514-1525

Rabinowitz YS (1998) Keratoconus. Surv Ophthalmol 42:297-319

Rosenfeld JA, Drautz JM, Clericuzio CL et al (2011) Deletions and duplications of developmental pathway genes in 5q31 contribute to abnormal phenotypes. Am J Med Genet A 155A:19061916. doi:10.1002/ajmg.a.34100

Saad A, Gatinel D (2010) Topographic and tomographic properties of forme fruste keratoconus corneas. Invest Ophthalmol Vis Sci 51:5546-5555. doi:10.1167/iovs.10-5369

Saee-Rad S, Hashemi H, Miraftab M et al (2011) Mutation analysis of VSX1 and SOD1 in Iranian patients with keratoconus. Mol Vis 17:3128-3136

Sahebjada S, Schache M, Richardson AJ et al (2013) Evaluating the association between keratoconus and the corneal thickness genes in an independent Australian population. Invest Ophthalmol Vis Sci 54:8224-8228. doi:10.1167/iovs.13-12982

Sahebjada S, Schache M, Richardson AJ et al (2014) Association of the hepatocyte growth factor gene with keratoconus in an Australian population. PLoS One 9:e84067. doi:10.1371/journal. pone. 0084067

Salouti R, Nowroozzadeh MH, Zamani M, Ghoreyshi M (2010) Combined anterior keratoconus and Fuchs' endothelial dystrophy: a report of two cases. Clin Exp Optom 93:268-270. doi:10.1111/j.1444-0938.2010.00492.x

Saravani R, Hasanian-Langroudi F, Validad M-H et al (2015) Evaluation of possible relationship between COL4A4 gene polymorphisms and risk of keratoconus. Cornea 34:318-322. doi:10.1097/ICO.0000000000000356

Sherwin T, Brookes NH (2004) Morphological changes in keratoconus: pathology or pathogenesis. Clin Exp Ophthalmol 32:211217. doi:10.1111/j.1442-9071.2004.00805.x

Shetty R, Nuijts RMMA, Nanaiah SG et al (2015) Two novel missense substitutions in the VSX1 gene: clinical and genetic analysis of families with keratoconus from India. BMC Med Genet 16:33. doi:10.1186/s12881-015-0178-x

Soler VJ, Tran-Viet K-N, Galiacy SD et al (2013) Whole exome sequencing identifies a mutation for a novel form of corneal intraepithelial dyskeratosis. J Med Genet 50:246-254. doi:10.1136/jmedgenet-2012-101325

Stabuc-Silih M, Ravnik-Glavac M, Glavac D et al (2009) Polymorphisms in COL4A3 and COL4A4 genes associated with keratoconus. Mol Vis 15:2848-2860

Stabuc-Silih M, Strazisar M, Hawlina M, Glavac D (2010) Absence of pathogenic mutations in VSX1 and SOD1 genes in patients with keratoconus. Cornea 29:172-176. doi:10.1097/ ICO.0b013e3181aebf7a

Stachs O, Bochert A, Gerber T et al (2004) The extracellular matrix structure in keratoconus. Ophthalmol Z Dtsch Ophthalmol Ges 101:384-389. doi:10.1007/s00347-003-0902-3

Steahly LP (1978) Keratoconus following contact lens wear. Ann Ophthalmol 10:1177-1179 
Sykakis E, Carley F, Irion L et al (2012) An in depth analysis of histopathological characteristics found in keratoconus. Pathology (Phila) 44:234-239. doi:10.1097/PAT.0b013e3283511b42

Synowiec E, Wojcik KA, Izdebska J et al (2013) Polymorphisms of the homologous recombination gene RAD51 in keratoconus and Fuchs endothelial corneal dystrophy. Dis Markers 35:353362. doi:10.1155/2013/851817

Synowiec E, Wojcik KA, Izdebska J et al (2014) Polymorphisms of the apoptosis-related FAS and FAS ligand genes in keratoconus and Fuchs endothelial corneal dystrophy. Tohoku J Exp Med 234:17-27

Synowiec E, Wojcik KA, Izdebska J et al (2015) Polymorphism of the LIG3 gene in keratoconus and Fuchs endothelial corneal dystrophy. Cell Mol Biol Noisy Gd Fr 61:56-63

Tang YG, Rabinowitz YS, Taylor KD et al (2005) Genomewide linkage scan in a multigeneration Caucasian pedigree identifies a novel locus for keratoconus on chromosome 5q14.3q21.1. Genet Med Off J Am Coll Med Genet 7:397-405. doi:10.109701.GIM.0000170772.41860.54

Tang YG, Picornell Y, Su X et al (2008) Three VSX1 gene mutations, L159M, R166W, and H244R, are not associated with keratoconus. Cornea 27:189-192. doi:10.1097/ICO.0b013e31815a50e7

Tanwar M, Kumar M, Nayak B et al (2010) VSX1 gene analysis in keratoconus. Mol Vis 16:2395-2401

Toprak I, Kucukatay V, Yildirim C et al (2014) Increased systemic oxidative stress in patients with keratoconus. Eye Lond Engl 28:285-289. doi:10.1038/eye.2013.262

Tuft SJ, Hassan H, George S et al (2012) Keratoconus in 18 pairs of twins. Acta Ophthalmol (Copenh) 90:e482-e486. doi:10.1111/j.1755-3768.2012.02448.x

Tyynismaa H, Sistonen P, Tuupanen S et al (2002) A locus for autosomal dominant keratoconus: linkage to $16 \mathrm{q} 22.3-\mathrm{q} 23.1$ in Finnish families. Invest Ophthalmol Vis Sci 43:3160-3164

Udar N, Kenney MC, Chalukya M et al (2004) Keratoconus-no association with the transforming growth factor beta-induced gene in a cohort of American patients. Cornea 23:13-17

Udar N, Atilano SR, Brown DJ et al (2006) SOD1: a candidate gene for keratoconus. Invest Ophthalmol Vis Sci 47:3345-3351. doi:10.1167/iovs.05-1500

Vazirani J, Basu S (2013) Keratoconus: current perspectives. Clin Ophthalmol Auckl NZ 7:2019-2030. doi:10.2147/OPTH. S50119

Verma A, Das M, Srinivasan M et al (2013) Investigation of VSX1 sequence variants in South Indian patients with sporadic cases of keratoconus. BMC Res Notes 6:103. doi:10.1186/1756-0500-6-103

Villanueva A, Willer JR, Bryois J et al (2014) Whole exome sequencing of a dominant retinitis pigmentosa family identifies a novel deletion in PRPF31. Invest Ophthalmol Vis Sci 55:2121-2129. doi:10.1167/iovs.13-13827

Vincent AL, Jordan C, Sheck L et al (2013) Screening the visual system homeobox 1 gene in keratoconus and posterior polymorphous dystrophy cohorts identifies a novel variant. Mol Vis 19:852-860

Vincent AL, Jordan CA, Cadzow MJ et al (2014) Mutations in the zinc finger protein gene, ZNF469, contribute to the pathogenesis of keratoconus. Invest Ophthalmol Vis Sci 55:5629-5635. doi:10.1167/iovs.14-14532

Vitart V, Bencić G, Hayward C et al (2010) New loci associated with central cornea thickness include COL5A1, AKAP13 and AVGR8. Hum Mol Genet 19:4304-4311. doi:10.1093/hmg/ ddq349

Vithana EN, Aung T, Khor CC et al (2011) Collagen-related genes influence the glaucoma risk factor, central corneal thickness. Hum Mol Genet 20:649-658. doi:10.1093/hmg/ddq511

Wang Y, Jin T, Zhang X et al (2013) Common single nucleotide polymorphisms and keratoconus in the Han Chinese population. Ophthalmic Genet 34:160-166. doi:10.3109/13816810.2012.7 43569

Weiss JS, Møller HU, Lisch W et al (2008) The IC3D classification of the corneal dystrophies. Cornea 27(Suppl 2):S1-S83. doi:10.1097/ICO.0b013e31817780fb

Wilson SE, He YG, Weng J et al (1996) Epithelial injury induces keratocyte apoptosis: hypothesized role for the interleukin-1 system in the modulation of corneal tissue organization and wound healing. Exp Eye Res 62:325-327. doi:10.1006/ exer.1996.0038

Wilson CM, D'Ath PJ, Parmar DN, Sykakis E (2014) Keratoconus and granular dystrophy. BMJ Case Rep. doi:10.1136/ bcr-2014-205584

Wojcik KA, Blasiak J, Szaflik J, Szaflik JP (2014a) Role of biochemical factors in the pathogenesis of keratoconus. Acta Biochim Pol 61:55-62

Wojcik KA, Synowiec E, Polakowski P et al (2014b) Polymorphism of the flap endonuclease 1 gene in keratoconus and Fuchs endothelial corneal dystrophy. Int J Mol Sci 15:14786-14802. doi:10.3390/ijms150814786

Wójcik KA, Synowiec E, Jiménez-García MP et al (2013) Polymorphism of the transferrin gene in eye diseases: keratoconus and Fuchs endothelial corneal dystrophy. BioMed Res Int 2013:247438. doi: $10.1155 / 2013 / 247438$

Zhao F, Wu J, Xue A et al (2013) Exome sequencing reveals CCDC111 mutation associated with high myopia. Hum Genet 132:913-921. doi:10.1007/s00439-013-1303-6 